\title{
SOME SNOUT MITES FROM JAPAN (ACARINA: BDELLIDAE)
}

\author{
$\operatorname{AUTHOR}(\mathrm{S})$ :
}

Ehara, Shozo

CITATION:

Ehara, Shozo. SOME SNOUT MITES FROM JAPAN (ACARINA:

BDELLIDAE). PUBLICATIONS OF THE SETO MARINE BIOLOGICAL

LABORATORY 1961, 9(2): 247-263

\section{ISSUE DATE:}

1961-12-20

URL:

http://hdl.handle.net/2433/175293

RIGHT: 


\section{SOME SNOUT MITES FROM JAPAN \\ (ACARINA : BDELLIDAE) $)^{122}$}

SHÔzô EHARA

Zoological Institute, Faculty of Science, Hokkaido University

With 37 Text-figures

Bdellid mites, often called snout mites, are known to prey on small arthropods and their eggs. These mites are found in various habitats, e.g., soil, plants, caverns, and intertidal zone of sea shores. There is little information about bdellids from Japan and its adjacent regions (KARSCH, 1881; KISHIDA, 1927, 1935 ; Thor and Uchida, 1933; Asanuma, 1947; Ehara, 1960a).

In the present paper the following six species are recognized from this country :

Bdella longicornis (LinNaEus)

Bdella uchidai n. sp.

Neomolgus littoralis (LinnaEus)

Thoribdella simplex Aтyeo

Thoribdella japonica $\mathrm{n}$. sp.

Bdellodes longirostris (HERMANN)

This study is based on a small collection of bdellids taken from several localities in Japan during recent years. The holotypes, allotypes and part of the paratypes of the new species are preserved in the Zoological Institute, Hokkaido University; the remainder of the paratypes are deposited in the personal collection of Dr. Warren T. Atyeo, Department of Entomology, University of Nebraska, Lincoln, Nebraska, U.S.A.

The descriptive terms used are mainly those of Atyeo (1960). When setae are variable individually in number, their numbers are generally given as minimums, maximums, and modes; for example, "8 (7-11)" would indicate that the mode is 8 , the minimum is 7 , and the maximum is 11 . Whenever the minimum and maximum numbers of setae are given in the species of which a single specimen is available, the numbers are different right and left. For the numerous synonymies of the named species, see ThOR (1931) and Atyeo (1960).

1) Contribution No. 513 from the Zoological Institute, Faculty of Science, Hokkaido University, Sapporo, Japan.

2) This work was supported by grants from the Scientific Research Fund of the Ministry of Education.

Publ. Seto Mar. Biol. Lab., IX (2), 1961. (Article 13) 


\section{Bdella longicornis (LinNaEus)}

(Figs. 1-3)

Acarus longicornis Linnaeus, 1758, Syst. Nat., ed. 10, p. 618.

Female. Body, including rostrum, 1500 $\mu$ long. Chelicera (Fig. 1), 400 $\mu$ long, longitudinally finely striated, with 2 setae; movable digit slightly surpassing fixed

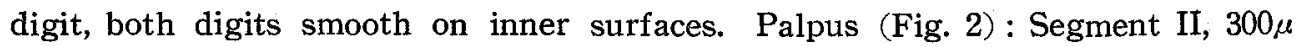
long, with 14-15 setae; III, $44 \mu$ long, with 1 seta; IV, $31 \mu$ long, with 4 setae; V, $113 \mu$ long, with 7 setae including 1 short sensory seta and 2 macrosetae $(369 \mu$ and $300 \mu$ ). Gnathosomal base striated, buccal cone (Fig. 3) finely striated. Ventral hypostomal setae as shown in Fig. 3; dorsal hypostomal setae absent. Legs: Claws

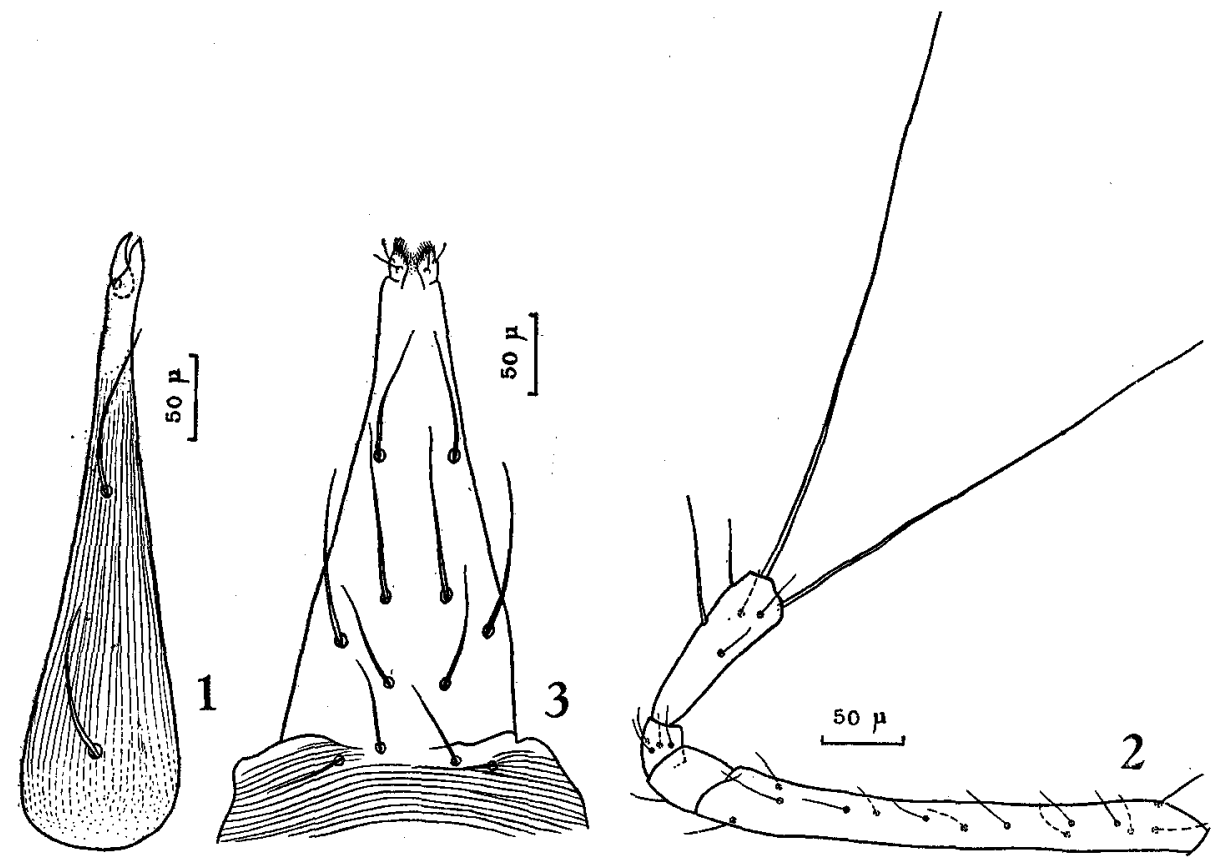

Figs. 1-3. Bdella longicornis ( 9 ). 1, chelicera. 2, palpus. 3, hypostome.

with 4-5 lateral rays each. Trochanter I, $78 \mu$ long, with 1 tactile seta; basifemur I, $181 \mu$ long, with 14 tactiles; telofemur I, 113 $\mu$ long, with 13-14 tactiles; genu I, $81 \mu$ long, with 9 tactiles, 4 slender sensory setae, 1 set of duplex setae; tibia I, $169 \mu$ long, with 16 tactiles, 6 slender sensory setae, 1 set of duplex setae, trichoboth; tarsus I, $231 \mu$ long, with 14 nude dorsals, 4 plumose dorsoterminals, 16 ventrals (distal ones plumose), 2 broad, blunt and 2 slender sensory setae, 1 peg. Trochanter II, $78 \mu$ long, with 1 tactile; basifemur II, $150 \mu$ long, with 13 tactiles; telofemur II, $94 \mu$ long, with 12-13 tactiles; genu II, $75 \mu$ long, with 9 tactiles, 2 slender sensory setae, 1 set of duplex setae; tibia II, $138 \mu$ long, with 
15 tactiles, 1 broad, blunt and 3 slender sensory setae; tarsus II, $213 \mu$ long, with 13 nude dorsals, 4 plumose dorsoterminals, 14 ventrals (distal ones plumose), 2 broad, blunt sensory setae, 1 peg. Trochanter III, $100 \mu$ long, with 2 tactiles; basifemur III, $194 \mu$ long, with 12 tactiles ; telofemur III, $113 \mu$ long, with 11 tactiles ; genu III, $94 \mu$ long, with 9 tactiles, 2 slender sensory setae, 1 set of duplex setae; tibia III, $169 \mu$ long, with 16 tactiles, 1 slender sensory seta ; tarsus III, 269 $\mu$ long, with 11 nude dorsals, 4 plumose dorsoterminals, 14 ventrals (distal ones plumose), trichoboth. Trochanter IV, $138 \mu$ long, with 2 tactiles; basifemur IV, $200 \mu$ long, with 6 tactiles; telofemur IV, $125 \mu$ long, with 8 tactiles; genu IV, $125 \mu$ long, with 10 tactiles, 3 slender sensory setae ; tibia IV, $200 \mu$ long, with 14 tactiles, trichoboth ; tarsus IV, $288 \mu$ long, 9 nude dorsals, 4 plumose dorsoterminals, 14 ventrals (distal ones plumose), 1 slender sensory seta, trichoboth. Dorsal integumentary striae on propodosoma finely broken, area between anterior and posterior sensilla with transverse striae; median and lateral propodosomals nude, shorter than posterior sensillum; interval between anterior sensilla, $119 \mu$; distance between two eyes slightly longer than diameter of anterior eye. Dorsal hysterosomal setae apparently nude, long and slender, but shorter than intervals to bases of setae next behind, except for caudal setae reaching to their succeeding bases. Border striae of anal cleft parallel; 1 pair of anal setae and 5 pairs of paranal setae; postanals cephalad of dorsal termination of anal cleft, slightly longer than external clunals. Each genital plate with 8 genital setae; genital discs normal; number of paragenital setae not determined (According to Aтуео, 1960, 9-10 pairs occurring in the New World specimens); ovipositor with 20 setae.

Male. Not available to the author.

Specimen examined. Female, Sapporo, Hokkaido, 10-VII-1958 (on earth), S. Ehara leg.

Distribution. Asia, Europe, North and Central America, and in Japan (first record) : Hokkaido.

Remarks. Referring to Atyeo's description (1960), the present material is different from his materials in having additional sensory setae on genua III and IV.

\section{Bdella uchidai n. sp.}

(Figs. 4-12)

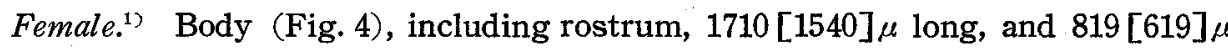
wide, somewhat purplish red in colour. Chelicera. (Fig. 5), 475 [388] $\mu$ long, longitudinally finely striated, with 2 setae; movable digit slightly surpassing fixed

1) Bdella uchidai is variable locally: specimens from Ranshima, Osyoro and Hariusu are considerably different from those from Akkeshi. This description is based on these two groups of specimens; nonbracketed numerical values are data obtained from the former group, while bracketed values are from the latter group. Whenever data from the two groups are identical, a nonbracketed value is only given. 
digit, both digits nearly smooth on inner surfaces. Palpus (Fig. 6) : Segment I, 31 [29] $\mu$ long; II, 331 [288] $\mu$ long, with 15(13-15) [14] setae; III, 73 [44-63] $\mu$ long, with 1 seta; IV, 50[38-44] $\mu$ long, with 4 setae; V, 169 [119-138] $\mu$ long, with 7 [7-8] setae including 1 short sensory seta and 2 macrosetae $(375$ [250-338] $\mu$ and $344[225-313] \mu)$. Gnathosomal base striated, buccal cone (Fig. 7) with striations fine. Ventral hypostomal setae as shown in Fig. 7; dorsal hypostomal setae wanting. Legs (Figs. 11, 12) : Claws with 6 lateral rays each. Trochanter I,

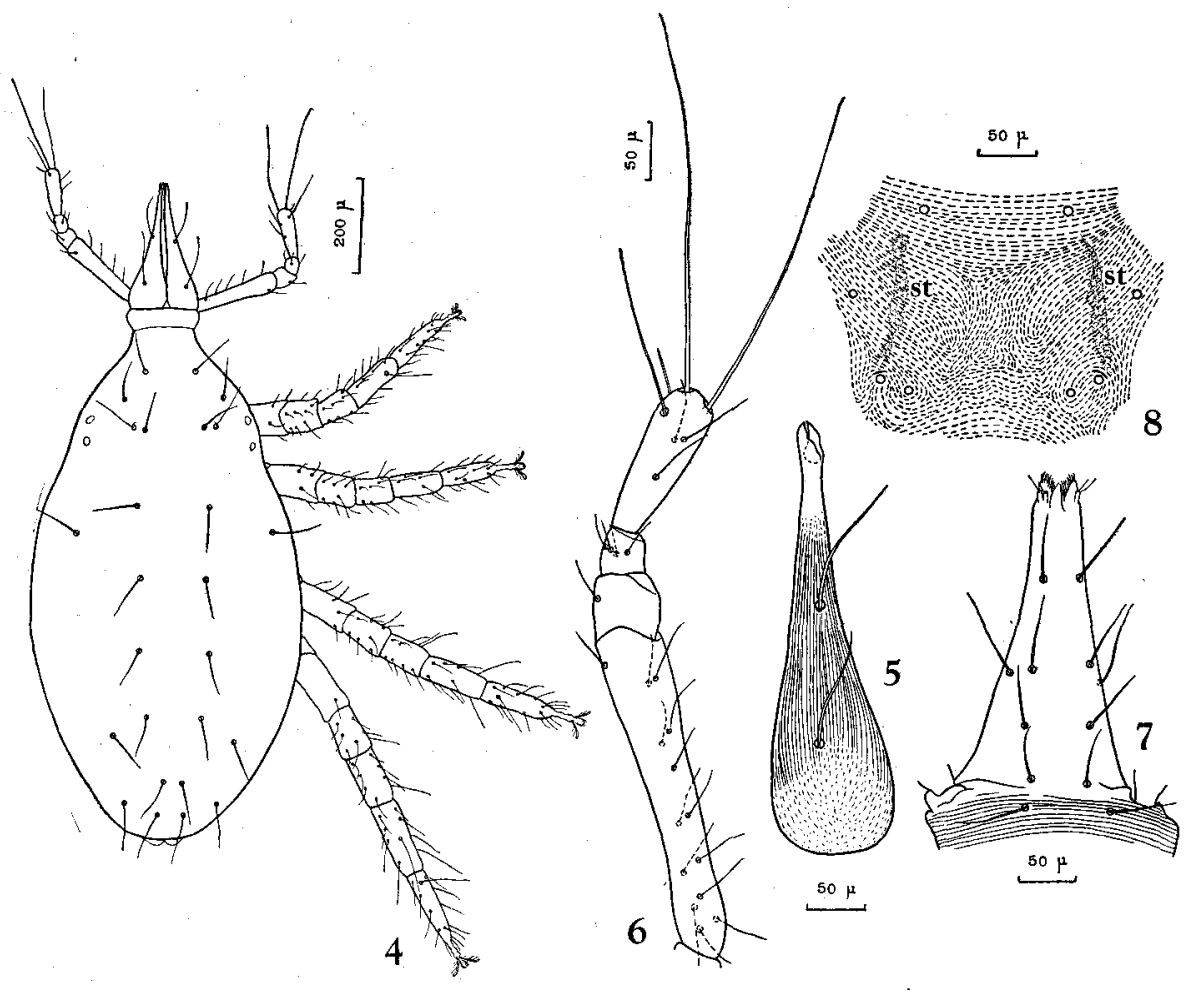

Figs. 4-8. Bdella uchidai n. sp. (Akkeshi). 4, dorsal view of body $(\hat{\delta})$. 5 , chelicera $(o) .6$, palpus $(o) .7$, hypostome $(\delta) .8$, dorsal integumentary striation of propodosoma $(\hat{\delta})$; st, subcutaneous thickenings.

113 [104] $\mu$, with $2(2-3)$ [2] tactile setae; basifemur I, 231 [213] $\mu$ long, with 15 (15-19) [14(13-14)] tactiles; telofemur I, 144 [119] $\mu$ long, with 13(13-16) [12(12-13)] tactiles, 2(1-2) [0] slender sensory setae; genu I, $106[131] \mu$ long, with $10(9-10)$ tactiles, $8(6-8)$ [6] slender sensory setae, 1 set of duplex setae ; tibia I, 213 [181] $\mu$ long, with 16(16-18) tactiles, 6-9[7(6-7)] slender sensory setae, 1 set of duplex setae, trichoboth; tarsus I, 256 [219] $\mu$ long, with 14 dorsals (2-4 distal ones minutely plumose), 4 plumose dorsoterminals, 16 ventrals $(14[14(12-14)]$ ones 
plumose), 2 broad, attenuate and 2 adjacent, slender sensory setae, 1 peg. Trochanter II, 119 [106] $\mu$ long, with 2 tactiles; basifemur II, 219 [181] $\mu$ long, with 13-15 [12-14] tactiles; telofemur II, 138 [119] $\mu$ long, with 14(14-17) [13(12-13)] tactiles, $0(0-1)$ [0] slender sensory seta; genu II, 125 [106] $\mu$ long, with 10 tactiles, $3(3-4)$ slender sensory setae, 1 set of duplex setae; tibia II, 188 [163] $\mu$ long, with 17(16-17) [17] tactiles, 1 broad, blunt and 6 [5] slender sensory setae; tarsus II, 263 [219] $\mu$ long, with 13 dorsals (1-3 distal ones minutely plumose), 4 plumose dorsoterminals, 14 ventrals (12(11-12) [10-12] ones plumose), 2 broad, attenuate sensory setae, 1 peg. Trochanter III, $163[138] \mu$ long, with 3(3-4) [4] tactiles ; basifemur III, $256[219] \mu$ long, with 11-13[12(12-13)] tactiles; telofemur III,

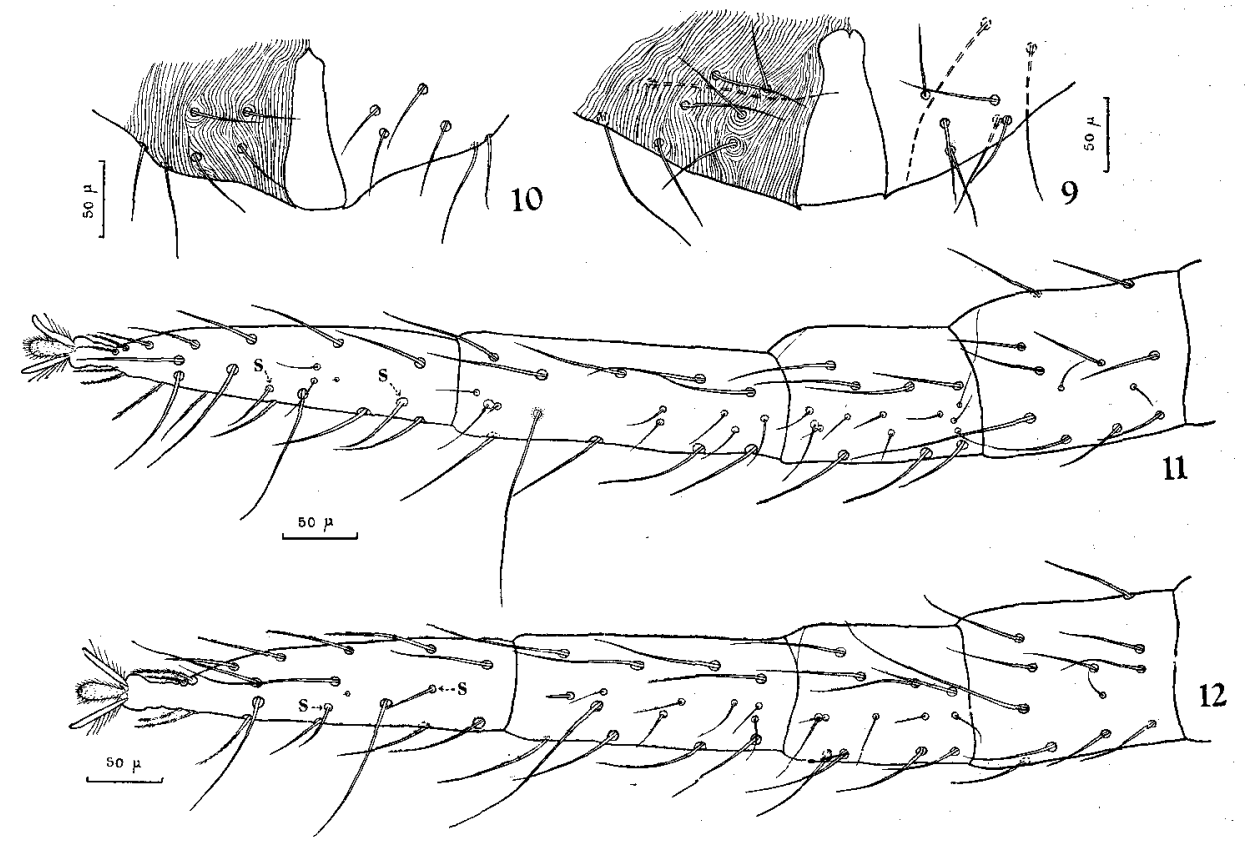

Figs. 9-12. Bdella uchidai n. sp. $9 \& 10$, showing variation of chaetotactic pattern of anal region: 9, Ranshima, s; 10, Akkeshi, o. 11, leg I (Ranshima, of); s, attenuate, broad sensory seta. 12, leg II (Ranshima, 우).

144 [125] $\mu$ long, with 11-15[10-12] tactiles; genu III, 144[125] $\mu$ long, with 11 (10-12) [9-11] tactiles, 3(2-3) [2(2-3)] slender sensory setae, 1 set of duplex setae ; tibia III, 231 [194] $\mu$ long, with 17-20[18-20] tactiles, 1(1-3) [2(2-3)] slender sensory seta ; tarsus III, 313 [269] $\mu$ long, with 11 dorsals (1-2 distal ones minutely plumose), 4 plumose dorsoterminals, 14 ventrals $(8[6(6-8)]$ ones plumose), trichoboth. Trochanter IV, 213 [175] $\mu$ long, with $3-5$ [3] tactiles; basifemur IV, 269 [238] $\mu$ long, with 5-7[5] tactiles; telofemur IV, 169 [144] $\mu$ long, with 11-15[10-13] tactiles; genu IV, 181 [156] $\mu$ long, with 9-12 [10-11] tactiles, 4(3-4) slender sensory setae; tibia IV, 275 [231] $\mu$ long, with 20(18-20) [18(17-18)] tactiles, 1(1-2) [1] 
slender sensory seta, trichoboth ; tarsus IV, 356 [300] $\mu$ long, with 10(10-11) dorsals (0-1 distal one minutely plumose), 4 plumose dorsoterminals, 14(14-16) [14] ventrals (8(8-9) [6-8] ones plumose), 1 slender sensory seta, trichoboth. Dorsal integumentary striae on propodosoma (Fig. 8) finely broken; area between anterior and posterior sensilla with transverse striae anteriorly, with irregularly longitudinal striae centrally, and with transverse (convex) striae posteriorly; internal subcutaneous thickenings (Fig. 8) small in extent; median and lateral propodosomals apparently nude, as long as anterior and posterior sensilla each; interval between anterior sensilla, 138 [119] $\mu$; distance between two eyes as long as diameter of posterior eye. Dorsal hysterosomal setae very finely plumose, shorter than distances to bases of setae next behind, except for caudal setae; sacrals and clunals each arranged in gently curving transverse row. Border striae of anal cleft parallel ; 2(2-3) pairs of anal setae and 5(4-5) pairs of paranals (Figs. 9, 10) ; postanals inserted cephalad of dorsal termination of anal cleft, as long as clunals. Each genital plate with 8-12 genital setae; genital discs normal; 19(16-20) pairs of paragenitals; ovipositor with 20 setae.

Male. Smaller than female and generally similar to that sex. Number of slender sensory setae on legs: telofemur I, $0-2[0(0-1)]$; genu I, 7(5-7) [4-5]; genu II, 4(3-4) [2(2-3)]; tibia II, 5(5-7) [4(4-5)]; tibia III, 2[1]; genu IV, 4(2-4) [3]; tibia IV, 1(1-2) [0(0-1)]. Number of tactile setae: tibia II, 16(16-17) [15 (14-17)]; basifemur III, 12(11-16) [10-11]; tibia III, 18-20 [15(14-18)]; tibia IV, 18(18-20) [14(14-17)]; tarsus IV, 11(9-11) [9]. Each genital plate with 9-10 genital setae; each amphioid sclerite with 6 anterior, 1 middle (smaller), and 2 posterior setae.

Holotype. Female, Ranshima, Hokkaido, 21-X-1957, M. Mizutani leg.

Allotype. Male, same data as holotype.

Paratypes. Four females and 10 males, same data as holotype; 1 female, Osyoro, Hokkaido, 12-VI-1957, M. Yamada \& S. Ozawa leg., 2 females, Hariusu, Hokkaido, 22-V-1958, S. Ehara leg.; 2 females and 2 males, Akkeshi, Hokkaido, 1-V-1957, M. Yamada \& K. Mikamo leg., 5 females and 4 males, Akkeshi, 27VI-1957, S. Ehara leg., 2 females and 3 males, Akkeshi, 28-VI-1957, S. Ehara leg.; 1 male, Hakodate, Hokkaido, 29-V-1957, S. Muramatsu leg.; 3 males, Shirahama, Wakayama Pref., Honshu, 24-II-1955, 18-VII-1955, H. Uтіnomi leg.

All the types were collected on the rocks or stones in the intertidal zone.

Remarks. Bdella uchidai is similar to Bdella longicornis but is different in chaetotactic patterns of the ventral gnathosoma and of the legs, particularly, in having more slender sensory setae on the legs and in having attenuate-broad sensory setae on tarsi I and II rather than blunt sensory setae. Further, this species is distinguished from the latter by irregularly longitudinal striae between the anterior and posterior sensilla, by generally nineteen pairs of paragenital setae, and by longer tactile setae on the palpus (excluding distal macrosetae). 
As seen in the above description this species varies locally (cf. foot-notes of page 249). Namely, specimens collected from Ranshima, Osyoro and Hariusu are considerably different from those from Akkeshi. Individuals from Hakodate and Shirahama are so few in number that can not be adequately examined, however they are of the Akkeshi type. On the coasts of Hokkaido, the two bdellid species, Neomolgus littoralis and B. uchidai, appear to be common; they can be distinguished in the field: the former is dark red in colour, while the latter is somewhat purplish red. This new species is named in honour of Prof. Tohru UchIDA.

\section{Neomolgus littoralis (LINNAEUS)}

(Figs. 13-19)

Acarus littoralis Linnaeus, 1758, Syst. Nat., ed. 10, p. 618.

Molgus littoralis, THOR \& UCHIDA, 1933, p. 138; KISHIDA, 1935, p. 142 ; ToKUNAGA, 1943, Iyô Kontyûgaku (=Medical Entomology), vol. 2, p. 1314.

Biscirus silvaticus (nec KRAMER), AsANUMA, 1947, p. 956, Fig. 2719.

Neomolgus littoralis, EhARA, 1960a, p. 9, Pl. 4, Fig. 14; EHARA, 1960b, p. 411.

Female. Body (Fig. 13), including rostrum, 2000-2500 $\mu$ long, and 775-1190 $\mu$ wide, dark red in colour. Chelicera (Fig. 14), 556 $\mu$ long, nonstriated, with 12(10-14) setae; movable digit flattened distally on inner surface, surpassing fixed digit which is remarkably bifurcate apically. Palpus (Fig. 15) : Segment I, 44 $\mu$ long; II, 394 $\mu$ long, with 5(4-7) setae; III, 69-88 $\mu$ long, with 1 seta ; IV, 106-150 $\mu$ long, with 4 setae; V, $419 \mu$ long, with $20(18-22)$ setae including 1 short sensory seta and 2 macrosetae (164 and $153 \mu$ ). Gnathosomal base striated, buccal cone (Fig. 16) nonstriated. Ventral hypostomal setae as shown in Fig. 16; dorsal hypostomal setae as long as, or shorter than $v h$ 1. Legs (Figs. 18, 19) : Claws with 6-7 lateral rays each. Trochanter I, 144 $\mu$ long, with 1 tactile seta; basifemur I, 269 $\mu$ long, with 12-17 tactiles; telofemur I, 144 $\mu$ long, with 7 tactiles; genu I, 144 $\mu$ long, with 6(6-7) tactiles, 16(14-23) slender sensory setae; tibia I, $225 \mu$ long, with 13(13-17) tactiles, 24(18-30) slender sensory setae, 1 peg, trichoboth; tarsus I, $400 \mu$ long, with $14(14-18)$ nude dorsals, 4 plumose dorsoterminals, 32(26-34) ventrals (19(17-22) ones plumose), 2 broad, blunt and 7-8(6-9) slender sensory setae, 1 peg. Trochanter II, $131 \mu$ long, with 1 tactile; basifemur II, 281 long, with 11-16 tactiles; telofemur II, $144 \mu$ long, with $7(7-8)$ tactiles; genu II, 144 $\mu$ long, with 6 tactiles, 12(9-17) slender sensory setae ; tibia II, $219 \mu$ long, with 11-15 tactiles, 1 broad, blunt and 17(14-21) slender sensory setae, trichoboth; tarsus II, $400 \mu$ long, with $14(13-17)$ nude dorsals, 3 plumose and 1 nude (sometimes, slightly plumose only proximally) dorsoterminals, 29 (24-34) ventrals (16(13-18) ones plumose), 2 broad, blunt and 2-7 slender sensory setae, 1 peg. Trochanter III, 144 $\mu$ long, with 1(1-3) tactile; basifemur III, 319 $\mu$ long, with $12(10-13)$ tactiles; telofemur III, 156 $\mu$ long, with 6(6-7) tactiles; genu III, $150 \mu$ long, with 6(6-7) tactiles, 
8(7-10) slender sensory setae; tibia III, $244 \mu$ long, with $15(13-17)$ tactiles, 4(4-9) slender sensory setae; tarsus III, $450 \mu$ long, with $12(11-12)$ nude dorsals, 2 plumose and 2 nude dorsoterminals, 29(25-34) ventrals (11-13 ones plumose), $0(0-3)$ slender sensory seta, trichoboth. Trochanter IV, $213 \mu$ long, with 3(2-4) tactiles; basifemur IV, $338 \mu$ long, with 6(5-8) tactiles; telofemur IV, $181 \mu$ long, with 6(6-8) tactiles; genu IV, $200 \mu$ long, with $8(6-8)$ tactiles, 5(4-7) slender sensory setae; tibia IV, $325 \mu$ long, with 16(13-17) tactiles, $3-4(0-4)$ slender sensory setae, trichoboth; tarsus IV, $488 \mu$ long, with $11(9-12)$ nude dorsals, 2 plumose and 2 nude dorsoterminals, $20-29$ ventrals $(7(6-8)$ ones plumose), $0(0-1)$ slender sensory seta,

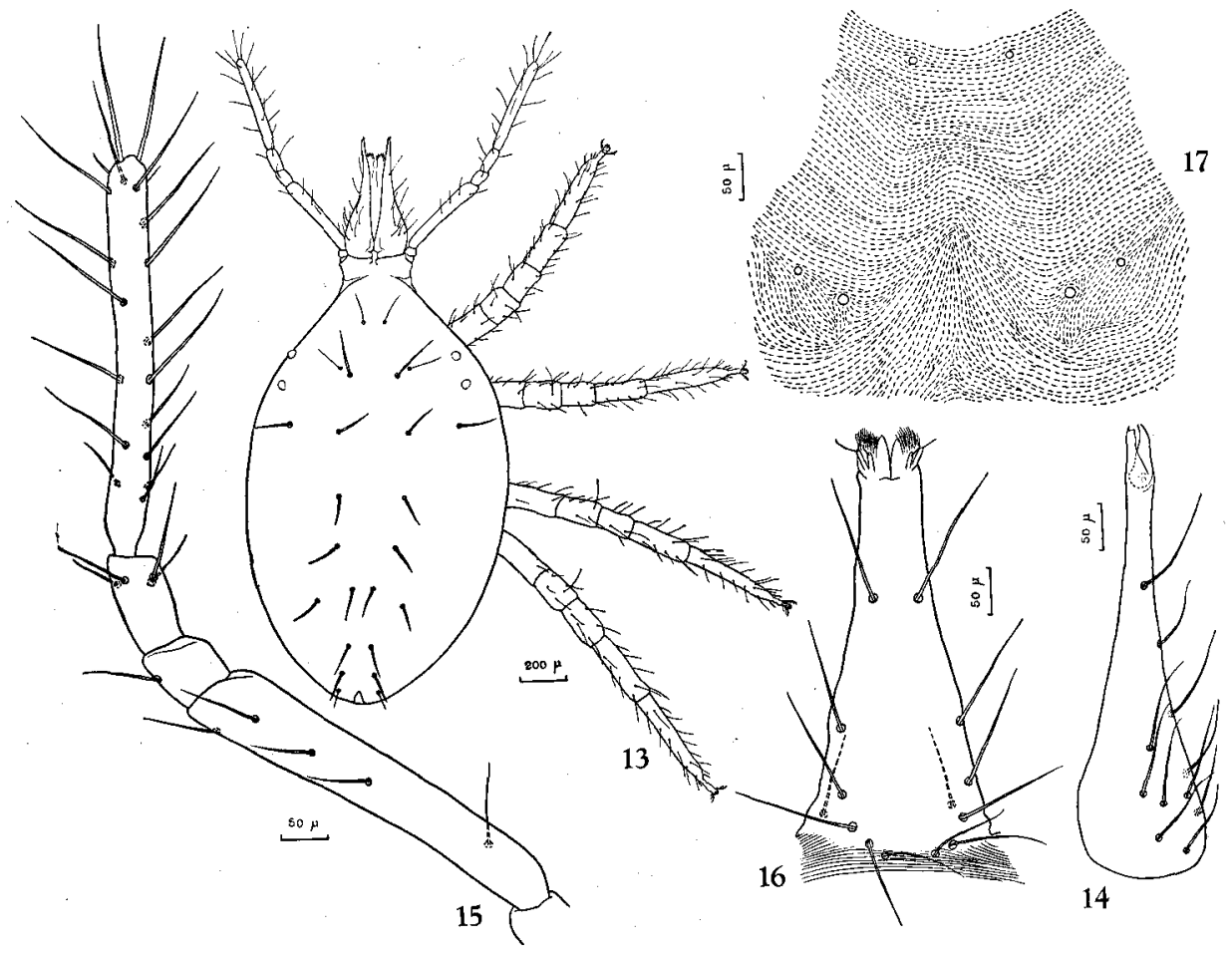

Figs. 13-17. Neomolgus littoralis. 13, dorsal view of body ( $\delta$ ). 14, chelicera ( $ᄋ$ ). 15 , palpus ( $\%$ ). 16, hypostome ( $ᄋ$ ). 17, dorsal integumentary striation

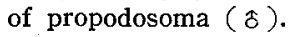

trichoboth. Dorsal integumentary striae on propodosoma (Fig. 17) finely broken; area between anterior and posterior sensilla with transverse striae anteriorly, and with longitudinal striae posteriorly; median propodosomal setae apparently nude, longer than anterior and posterior sensilla each, interval between anterior sensilla, $94 \mu$; lateral propodosomals absent; distance between two eyes twice to three times as long as diameter of anterior eye. Dorsal hysterosomal setae finely plumose, shorter than distances to bases of setae next behind, except for caudal pairs. Border striae of anal cleft parallel ; anal setae absent ; paranals one-paired ; 
postanals inserted at level of dorsal termination of anal cleft, shorter than clunals. Each genital plate with $12(8-12)$ genital setae; genital discs large; paragenital setae seven-paired ( 2 anterior, 2 middle and 3 posterior); ovipositor with 20 setae.

Male. Smaller than female and generally similar to that sex. Ventral hypostomal setae six-paired but sometimes five-paired. Slender sensory setae on leg I varying in number more widely than in female; maximum number (loc. Akkeshi) of these setae: genu, 25 ; tibia, 31 ; tarsus, 11 . Genu II with 6-7 tactiles. Each genital plate with $10(10-16)$ genital setae; each amphioid sclerite with 3 anterior, 4 middle, and 2 posterior setae (sometimes with 4 anterior, 3 middle, and 2 posterior setae).

Specimens examined. Two females and 1 male, Osyoro, Hokkaido, 12-VI-1957, M. Yamada \& S. Ozawa leg., 2 females, Osyoro, 25-VI-1957, Y. Akahira \& Z. NAGAo leg.; 2 females and 4 males, Akkeshi, Hokkaido, 27-VI-1957, S. Ehara

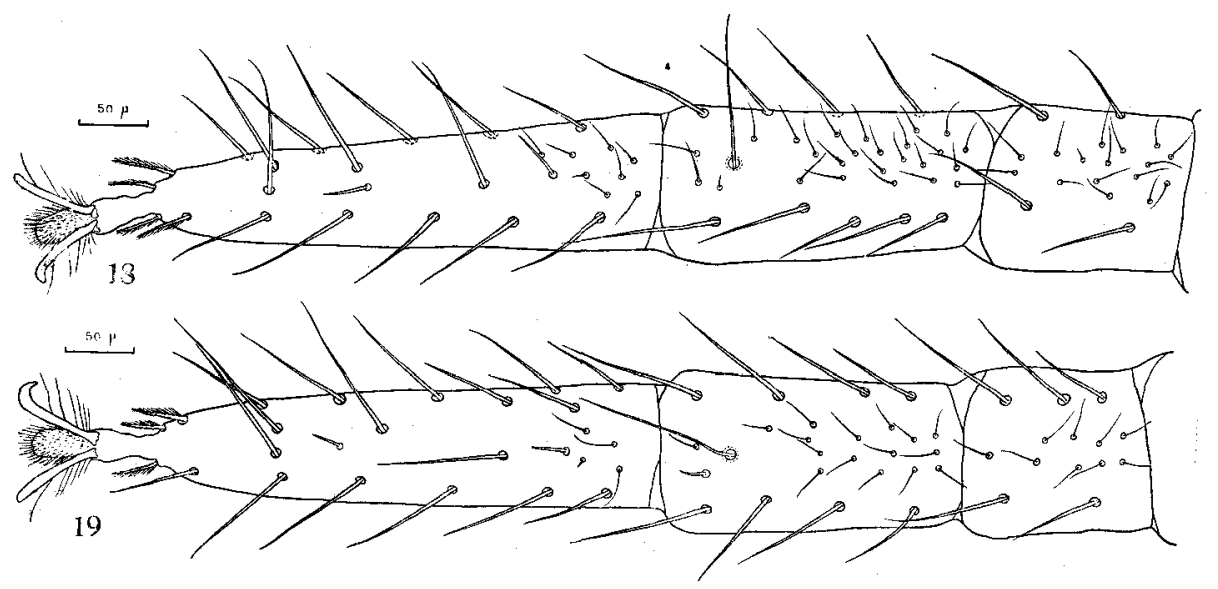

Figs. 18, 19. Neomolgus littoralis (\%). 18, leg I. 19, leg II.

leg., 1 female, Akkeshi, 28-VI-1957, S. Ehara leg. ; 2 females, Hakodate, Hokkaido, 29-V-1957, S. Muramatsu leg.; 3 males, Hayama, Kanagawa Pref., Honshu, 21III-1957, T. Uchida leg.; 1 female, Usa, Kôchi Pref., Shikoku, 15-IV-1961, K. Morikawa leg.

The specimens were collected on stones and rocks and under seaweeds in the intertidal zone.

Distribution. Circumpolar. In Japan and its adjacent regions: the Island Alaid, Japan (Hokkaido, Honshu, Shikoku), and Formosa(?).

Remarks. Specimens from Hakodate, Hayama and Usa differ from those from Osyoro and Akkeshi in having one to three slender sensory setae on tarsus III instead of no sensory setae. Tarsus IV of the former is generally lacking sensory seta but rarely having one sensory seta (tarsus IV of the latter is always deficient in sensory setae). As regards the palpal chaetotaxy this species also varies locally; specimens from Hayama and Usa have more than four tactile setae on 
segment IV, while those from Osyoro, Akkeshi and Hakodate constantly bear four tactile setae. Referring to Atyeo's description (1960), specimens from Osyoro and Akkeshi are considerably different from his materials in having constantly four setae on palpal segment IV, in having more slender sensory setae on leg I and genu II, and in lacking sensory setae on tarsi III and IV.

This species has been recorded several times from Japan and its adjacent regions. THOR and UCHIDA (1933) recorded the mite from Alaid, the northernmost island of the Kurile Islands, while Kishida (1935) from Formosa, as well as from Kanagawa Prefecture and Wakayama Prefecture. The present author is slightly doubtful that KIsHide's specimens from Formosa, a subtropical island, were determined correctly.

\section{Thoribdella simplex ATYEO}

(Figs. 20-25)

Thoribdella simplex AтүeO, 1960, p. 405, Figs. 8, 23, 49, 103, 104, 147.

Female. Body, including rostrum, $2560 \mu$ long. Chelicera (Fig. 20), 488 $\mu$ long, nonstriated, with 2 setae; movable digit with inner surface flattened distally, surpassing fixed digit which is smooth on inner surface. Palpus (Fig. 21):
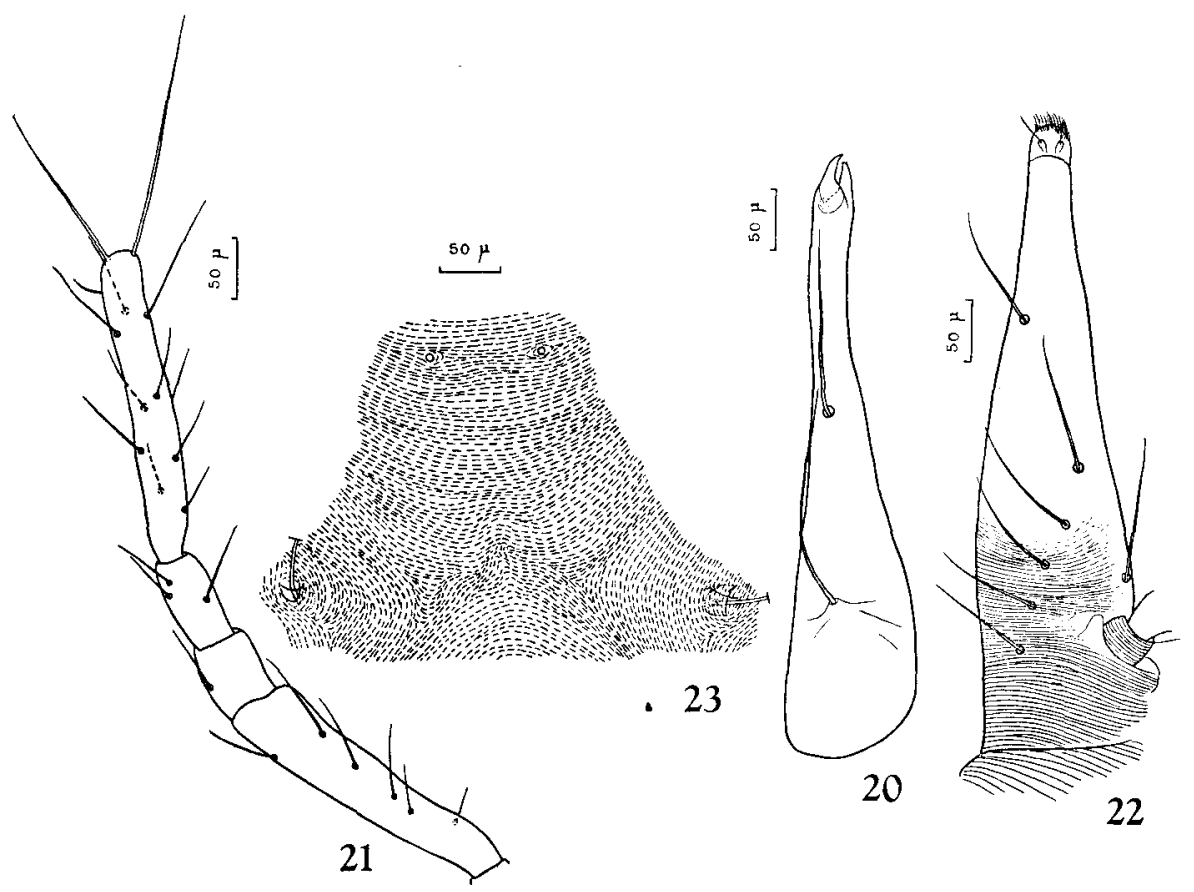

Figs. 20-23. Thoribdella simplex (o). 20, chelicera. 21, palpus. 22, hypostome. 23 , dorsal integumentary striation of propodosoma. 
Segment I, $37 \mu$ long; II, $250 \mu$ long, with 5-6 setae; III, $66 \mu$ long, with 1 seta; IV, $75 \mu$ long, with 3 setae; V, 250 $\mu$ long, with 13-14 setae including 1 short sensory seta and 2 macrosetae $(190$ and $175 \mu)$. Gnathosomal base striated, buccal cone (Fig. 22) striated only proximally. Ventral and dorsal hypostomal setae as shown in Fig. 22. Legs (Figs. 24, 25) : Claws with 7-8 lateral rays each. Trochanter I, $113 \mu$ long, with 1 tactile seta; basifemur. I, $275 \mu$ long, with 17 tactiles; telofemur I, $125 \mu$ long, with 10 tactiles ; genu I, $113 \mu$ long, with 6 tactiles, 8 slender sensory setae; tibia $I, 175 \mu$ long, with 15 tactiles, 11 slender sensory setae, 1 peg, trichoboth; tarsus I, $381 \mu$ long, with 13 nude dorsals, 4 plumose dorsoterminals, 44 ventrals ( 26 ones plumose), 2 broad, blunt and 3 slender sensory setae, 1 peg. Trochanter II, $125 \mu$ long, with 1 tactile; basifemur II, $313 \mu$ long, with 15-17 tactiles; telofemur II, $125 \mu$ long, with 10-11 tactiles; genu II, $119 \mu$ long, with 6 tactiles, 5-6 slender senosory setae; tibia II, $188 \mu$ long, with 14-15 tactiles, 1 broad,

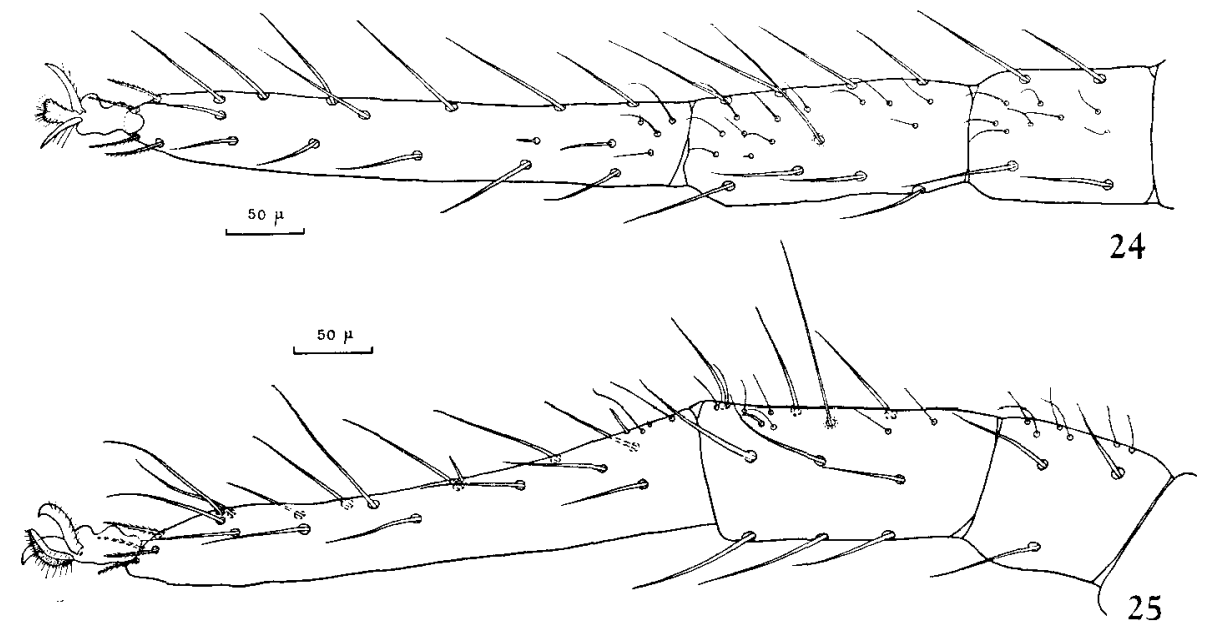

Figs. 24, 25. Thoribdella simplex (\%). 24, leg I. 25, leg II.

blunt and 5-7 slender sensory setae, trichoboth; tarsus II, 406 $\mu$ long, with 15-16 nude dorsals, 4 plumose dorsoterminals, 40-43 ventrals (25-27 ones plumose), 2 broad, blunt and 2 slender sensory setae, 1 peg. Trochanter III, 150 $\mu$ long, with 1-2 tactiles ; basifemur III, $325 \mu$ long, with 10-13 tactiles; telofemur III, $150 \mu$ long, with 8-9 tactiles; genu III, 131 $\mu$ long, with 6 tactiles, 5-6 slender sensory setae; tibia III, $238 \mu$ long, with 18 tactiles, 3 slender sensory setae; tarsus III, 444 $\mu$ long, with 13 nude dorsals, 4 plumose dorsoterminals, $42-43$ ventrals (20-23 ones plumose), trichoboth. Trochanter IV, $200 \mu$ long, with 1-2 tactiles; basifemur IV, $348 \mu$ long, with 8-9 tactiles; telofemur IV, 175 $\mu$ long, with 8 tactiles; genu IV, $169 \mu$ long, with 7-8 tactiles, 5-7 slender sensory setae; tibia IV, 281^ long, with 22 tactiles, trichoboth; tarsus IV, $488 \mu$ long, with 13 nude dorsals, 4 plumose dorsoterminals, 37-38 ventrals (15-16 ones plumose), trichoboth. Dorsal integumentary striae on propodosoma (Fig. 23) finely broken; area between anterior and posterior sensilla 
with concave, transverse striae on anterior and middle portions, and with convex, transverse striae on post-medial portion; posterior sensilla, $14 \mu$ Iong, approximate to median propodosomals which are nude, $313 \mu$ in length; distance between anterior sensilla, $94 \mu$; lateral propodosomals wanting; interval between two eyes longer than diameter of anterior eye. Dorsal hysterosomals finely plumose, much shorter than intervals to bases of setae next behind, except for external clunals barely reaching to postanals; internal humeral about two-fifth as long as distance to internal dorsal. Border striae of posterior anal cleft parallel; one pair of anal setae; paranals absent; postanals about flanking dorsal termination of anal cleft, as long as clunals. Each genital plate with 8 genital setae; genital discs normal; paragenital setae three-paired; ovipositor with 20 setae.

Male. Not available to the author.

Specimen examined. Female, Takanegahara (ca. $1800 \mathrm{~m}$ height above the sea), Mt. Daisetsu, Hokkaido, 5-VIII-1960 (under stone), S. F. Sakagami, K. Moriya \& M. Shrokawa leg.

Distribution. U.S.A.; Japan (first record) : Hokkaido.

Remarks. This identification is confirmed by Dr. Aтуeo. It is known that, in U.S.A., the species is extremely variable locally (AтYEO, 1960).

\section{Thoribdella japonica n. sp.}

(Figs. 26-32)

Female. Body (Fig. 26), including rostrum, $1940 \mu$ long and $890 \mu$ wide, pale red in colour. Chelicera (Fig. 27), $438 \mu$ long, nonstriated, with 2 setae; movable digit flattened distally on inner surface, much surpassing the fixed digit which is smooth on inner surface. Palpus (Fig. 28) : Segment I, $25 \mu$ long ; II, $213 \mu$ long, with 5-6 setae; III, $59 \mu$ long, with 1 seta; IV, $59 \mu$ long, with 3 setae; V, 181 long, with 11 setae including 1 short sensory seta and 2 macrosetae (206 $\mu$ and 156 $\mu$ ). Gnathosomal base striated, buccal cone (Fig. 29) striated proximally. Ventral hypostomal setae as shown in Fig. 29; dorsal hypostomals as long as, or longer than $v h 5$, and longer than $v h$ 1-4 and $v h 6$. Legs (Figs. 31, 32): Claws with 6-13 lateral rays each. Trochanter I, $119 \mu$ long, with 1 tactile seta; basifemur I, $244 \mu$ long, with 15-17 tactiles; telofemur I, $125 \mu$ long, with 10 tactiles; genu I, $106 \mu$ long, with $6(6-7)$ tactiles, $7(7-8)$ slender sensory setae; tibia I, 150 $\mu$ long, with 12(11-12) tactiles, 9(8-10) slender sensory setae, 1 peg, trichoboth; tarsus I, $319 \mu$ long, with 13 nude dorsals, 4 plumose dorsoterminals, 47(42-47) ventrals (29-33 ones minutely plumose), 2 broad, blunt and 2 slerder sensory setae, 1 peg. Trochanter II, $125 \mu$ long, with 1 tactile; basifemur II, 256 $\mu$ long, with $14-16$ tactiles; telofemur II, $119 \mu$ long, with 10 tactiles; genu II, $113 \mu$ long, with 6 tactiles, 4(4-5) slender sensory setae; tibia II, 163 $\mu$ long, with $12(11-12)$ tactiles, 1 broad, blunt and 6(5-6) slender sensory setae, trichoboth; tarsus II, 344 $\mu$ long, with 13 nude dorsals, 4 plumose dorsoterminals, $44-50$ ventrals $(30(29-30)$ ones minutely 
plumose), 2 broad, blunt and 1 slender sensory setae, 1 peg. Trochanter III, 134 $\mu$ long, with 1 tactile; basifemur III, 281 $\mu$ long, with 11(10-12) tactiles; telofemur III, 131 $\mu$ long, with 8 tactiles; genu III, 119 $\mu$ long, with 6 tactiles, 4 slender sensory setae; tibia III, 200 $\mu$ long, with 13(12-14) tactiles, 1 slender sensory seta; tarsus III, $400 \mu$ long, with 11 nude dorsals, 4 plumose dorsoterminals, $42-46$ ventrals (23-27 ones minutely plumose), trichoboth. Trochanter IV, 181 $\mu$ long, with 1 tactile; basifemur IV, 331 $\mu$ long, with 5(5-6) tactiles; telofemur IV, $163 \mu$ long, with 8(8-9) tactiles; genu IV, 156 $\mu$ long, with 6(6-7) tactiles, 4(4-5) slender sensory setae; tibia IV, 256 $\mu$ long, with 13(13-16) tactiles, trichoboth; tarsus IV,

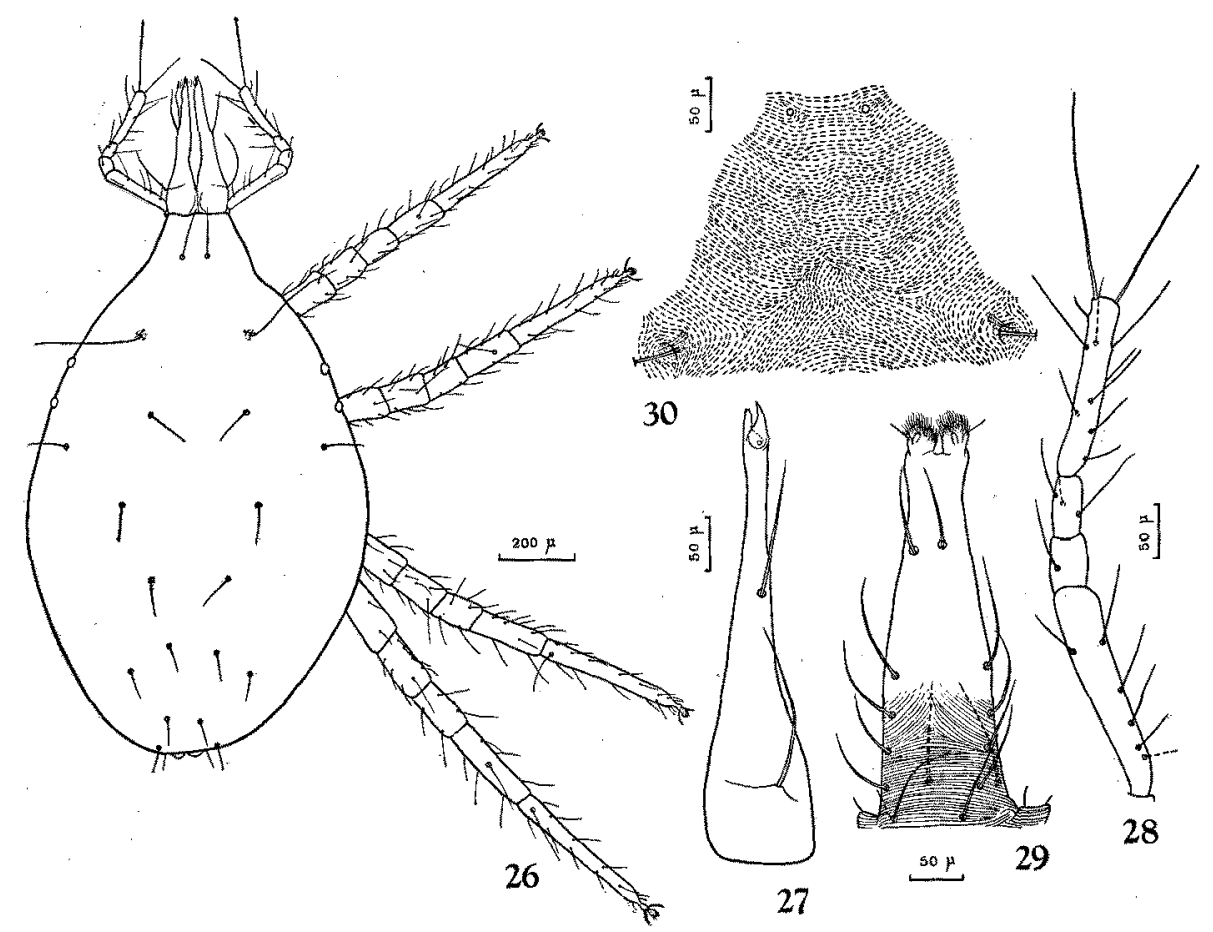

Figs. 26-30. Thoribdella japonica n. sp. (\%). 26, dorsal view of body. 27 , chelicera. 28 , palpus. 29 , hypostome. 30 , dorsal integumentary striation of propodosoma.

$425 \mu$ long, with $9(9-10)$ nude dorsals, 4 plumose dorsoterminals, $34-39$ ventrals (14-16 ones minutely plumose), trichoboth. Dorsal integumentary striae on propodosoma (Fig. 30) finely broken, area between anterior and posterior sensilla striated as figured; anterior sensilla, 150 $\mu$ long, posterior senilla, 31 $\mu$ long, approximate to median propodosomals which are nude, $300 \mu$ in length; distance between anterior sensilla, $75 \mu$; lateral propodosomals absent; interval between two eyes about twice as long as diameter of anterior eye. Dorsal hysterosomal setae finely plumose, much shorter than intervals to bases of setae next behind, except for 
clunals reaching to their succeeding bases; sacrals arranged in gently curving transverse row, clunals in strongly curving row. Border striae of anal cleft parallel ; anal setae one-paired; paranal setae lacking; postanals inserted at level slightly caudad of dorsal termination of anal cleft, shorter than clunals. Each genital plate bearing 8 genital setae; genital discs normal ; paragenital setae threepaired; ovipositor with 20 setae.

Male. Smaller than female. Each amphioid sclerite with 3 anterior, 4 middle, and 2 posterior setae.

Holotype. Female, Sapporo, Hokkaido, 8-IX-1959 (on ezo-spruce), S. EHARA leg.

Allotype. Male, same data as holotype.

Paratypes. Six females, same data as holotype; 1 female, 26-VIII-1959, other data same as in holotype.

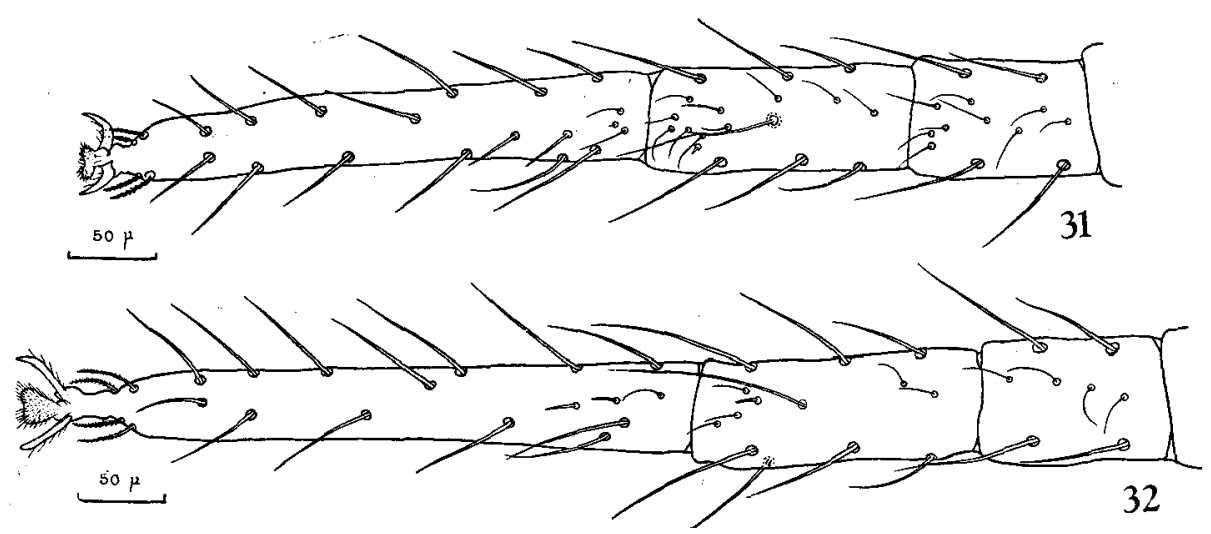

Figs. 31, 32. Thoribdella japonica n. sp. (ㅇ). 31, leg I. 32, leg II.

Remarks. This new species appears to be similar to symmetricus KRAMER and lapidarius KRAMER, both of which belong to the genus Thoribdella (ATYEO, in litt.). The new species is distinguished from symmetricus by the relative lengths of palpal segments II and V, and by the relative lengths of palpal macrosetae (ThOR, 1931; Womersley, 1933). This species is different from lapidarius in the relative lengths of two cheliceral setae, and in the relative lengths of segment $\mathrm{V}$ and macrosetae of palpus (Thor, 1931; WoMERsLey, 1933 ; BAKER and BALOCK, 1944).

\section{Bdellodes longirostris (HERMANN)}

(Figs. 33-37)

Scirus longirostris HeRMANN, 1804, Mém. Apt., p. 62.

Scirus longitarsa (nec KARSCH), KISHIDA, 1927, p. 975, Fig. 1877; KISHIDA, 1947, Illustr. Encycl. Fauna Jap., Rev. Ed., p. 955, Fig. 2718. 
Male. Body, including rostrum, $2190 \mu$ in length. Chelicera (Fig. 33), 569 $\mu$ long, nonstriated, with 1 seta; movable digit with a preapical tooth, slightly surpassing fixed digit which is provided with a prominent preapical tooth. Palpus (Fig. 34) : Segment I, $38 \mu$ long ; II, $438 \mu$ long, with $13-14$ setae ; III, $83 \mu$ long, with 1 seta; IV, $80 \mu$ long, with 4 setae; V, $412 \mu$ long, with 15 setae including 1 short sensory seta and 2 macrosetae $(266$ and $244 \mu)$. Gnathosomal base striated, buccal cone (Fig. 35) nonstriated. Ventral hypostomal setae as shown in Fig. 35; dorsal hypostomal setae as long as $v h$ 2. Legs (Figs. 36, 37): Claws with 6-7 lateral rays each. Trochanter I, $138 \mu$ long, with 1 tactile seta; basifemur I, 288 $\mu$ long, with 14-15 tactiles; telofemur I, 131 $\mu$ long, with 7 tactiles; genu I, $125 \mu$ long,

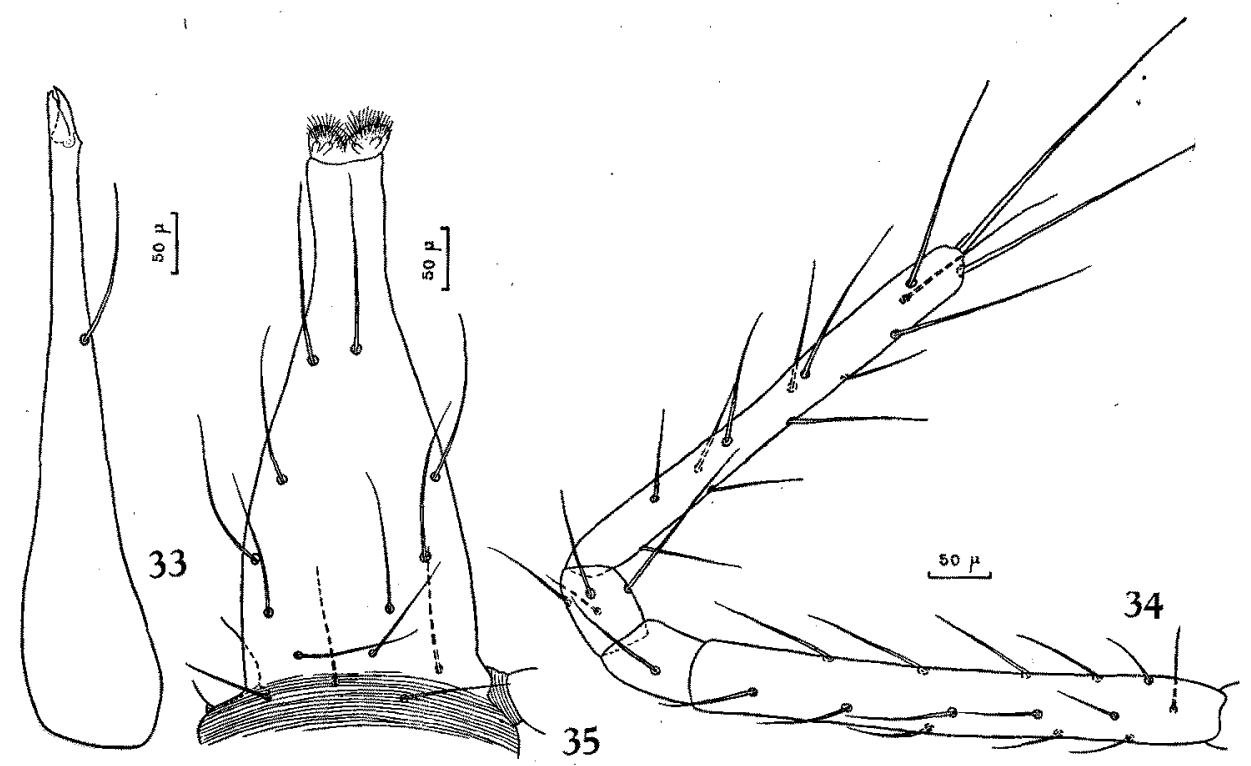

Figs. 33-35. Bdellodes longirostris ( $\delta$ ). 33, chelicera. 34, palpus. 35, hypostome.

with 6 tactiles, 4-5 slender sensory setae; tibia I, 194 $\mu$ long, with 12 tactiles, 3 slender sensory setae, 1 peg, trichoboth; tarsus $I, 425 \mu$ long, with 13-15 nude dorsals, 4 plumose dorsoterminals, 37 plumose ventrals (the more proximal ones the less plumose), 2 broad, blunt and 2 slender sensory setae, 1 peg. Trochanter II, $138 \mu$ long, with 1 tactile; basifemur II, 281 $\mu$ long, with 14-15 tactiles; telofemur II, $138 \mu$ long, with 7 tactiles; genu II, $125 \mu$ long, with 6 tactiles, 2-3 slender sensory setae; tibia II, 200 $\mu$ long, with 12 tactiles, 1 broad, blunt and 1 slender sensory setae, trichoboth; tarsus II, $438 \mu$ long, with 13-14 nude dorsals, 4 plumose dorsoterminals, 36-38 plumose ventrals (the more proximal ones the less plumose), 2 broad, blunt and 1 slender sensory setae, 1 peg. Trochanter III, $144 \mu$ long, with 1 tactile; basifemur III, $350 \mu$ long, with 12 tactiles; telofemur III, $150 \mu$ 
long, with 6 tactiles; genu III, $144 \mu$ long, with 6 tactiles, 2 slender sensory setae; tibia III, $250 \mu$ long, with $12-13$ tactiles, 1 slender sensory seta ; tarsus III, $494 \mu$ long, with 11-12 nude dorsals, 4 plumose dorsoterminals, 33-34 plumose ventrals (the more proximal ones the less plumose), trichoboth. Trochanter IV, $206 \mu$ long, with 1 tactile; basifemur IV, 381 $\mu$ long, with 5 tactiles; telofemur IV, $169 \mu$ long, with 6 tactiles; genu IV, $169 \mu$ long, with 5 tactiles, 2 slender sensory setae; tibia IV, $306 \mu$ long, with 11-13 tactiles, trichoboth; tarsus IV, 525 long, with 10 nude dorsals, 4 plumose dorsoterminals, 27 plumose ventrals (the more proximal ones the less plumose), trichoboth. Dorsal integumentary striae on propodosoma finely broken; median propodosomals inconspicuously plumose, as long as anterior and posterior sensilla each, interval between anterior sensilla, $88 \mu$; lateral propodosomals absent; distance between two eyes more than twice as long as diameter of

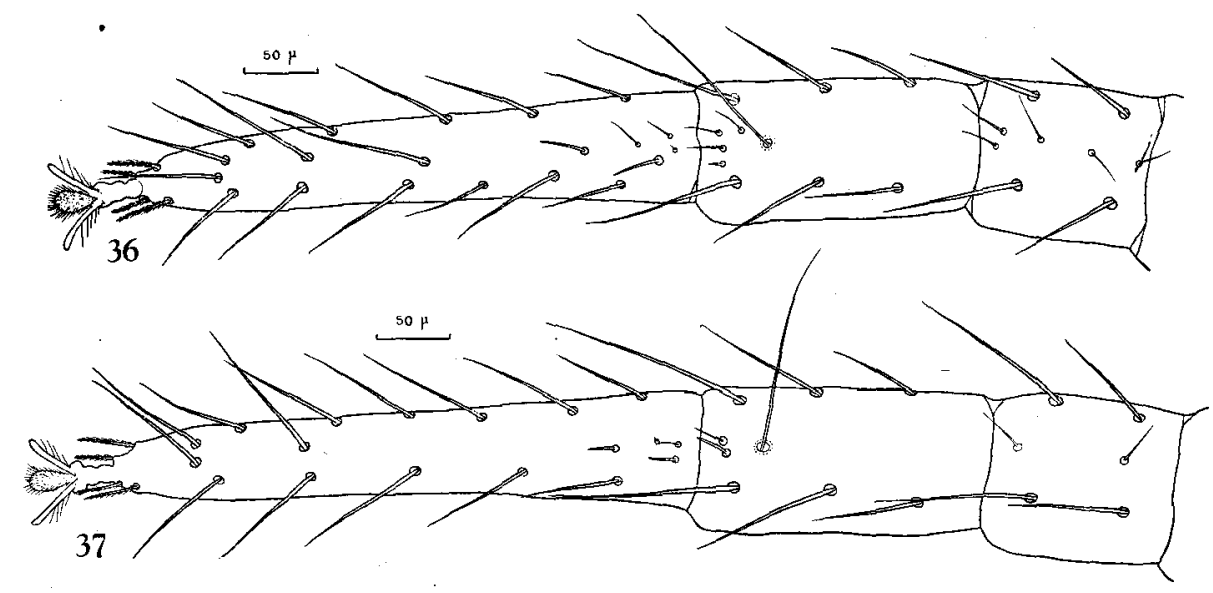

Figs. 36, 37. Bdellodes longirostris ( $\delta) .36$, leg I. 37 , leg II.

anterior eye. Dorsal hysterosomal setae finely plumose, shorter than intervals to bases of setae next behind, except for caudal pairs. Border striae of anal cleft parallel ; 1 pair of anal setae; paranals absent; postanals inserted at level slightly caudad of dorsal termination of anal cleft, shorter than clunalș. Each genital plate with 6 genital setae; middle and posterior genital discs adjacent on each side; number of paragenital setae not determined (According to Atyeo, 1960, 4-5 pairs located in the New World specimens); each amphioid sclerite with 3 anterior, 4 middle, and 2 posterior setae.

Female. Not available to the author.

Specimen examined. Male, Sapporo, Hokkaido, 2-VII-1958 (on earth), S. Ehara leg.

Distribution. Asia, Europe, North, Central and South America, Australia. In Japan (first record) : Hokkaido, Honshu, Shikoku, Kyushu. 
Remarks. It is of interest that, referring to Atyeo's illustrations (1960), two broad, blunt sensory setae on tarsi I and II are different in position between the New World and the Japanese specimens. These setae of the latter are located on the proximal portion of each tarsus, rather than on the middle portion.

From Honshu, Shikoku and Kyushu, a mite was recorded by KISHIDA (1927) under the name Scirus longitarsa $\left(\mathrm{KARSCH}_{\mathrm{A}}\right)$. Judging from his illustration, it is almost certain that the mite is really Bdellodes longirostris.

\section{Acknowledgements}

The author wishes to thank Professor Tohru UchIDA whose encouragement has constantly been offered. Sincere thanks are due to Dr. Warren T. Atreo who carefully examined some of the present material and kindly reviewed the manuscript of this paper. Further, acknowledgement is made to Dr. Huzio Utinomi, Dr. Kuniyasu Morikawa, Mr. Hiroyuki KamiYa and Dr. Mayumi Yamada for their kindness during the course of this study. The author is also indebted to the several collectors named in the text.

\section{REFERENCES}

Asanuma, K. 1947. Acarina (with K. Kishida \& T. UCHIDA). In: Illustr. Encycl. Fauna Jap., Rev. Ed., pp. 954-975. (In Japanese.)

Atyeo, W. T. 1960. A revision of the mite family Bdellidae in North and Central America (Acarina, Prostigmata). Univ. Kansas Sci. Bull., 40:345 499.

BAKer, E. W. \& J. W. BALOCK 1944. Mites of the family Bdellidae. Proc. Ent. Soc. Wash., $46: 176-184$.

Ehara, S. 1960a. Acarina (with T. Imamura \& K. Asanuma). In: Encycl. Zool. Illustr. in Col., $4: 9$, Pl. 4. (In Japanese.)

$1960 \mathrm{~b}$. Comparative studies on the internal anatomy of three Japanese trombidiform acarinids. J. Fac. Sci. Hokkaido Univ., Ser. VI Zool., 14: 410-434, 1 pl.

KARSCH, F. 1881. Diagnoses Arachnoidarum Japoniae. Berlin. Ent. Z., 25 : 35-40.

KIsHIDA, K. 1927. Acarina. In: Illustr. Encycl. Fauna Jap., 1st Ed,, pp. 973-986. (In Japanese.) 1935. Notes on the Acarina-mite and tick, from the Island of Formosa collected in August, 1935. Lansania, $7:$ 129-144.

Thor, S. 1931. Bdellidae, Nicoletiellidae, Cryptognathidae. Das Tierreich, 56: 1-64.

THOR, S. \& T. UchidA 1933. Acarinen aus den Nordkurilen. Bull. Biogeogr. Soc. Jap., $4: 137-138$. WOMERsLeY, H. 1933. A preliminary account of the Bdellidae (snout mites) of Australia. Trans. Roy. Soc. South Austr., 57 : 97-107. 